\section{Evaluering på norsk}

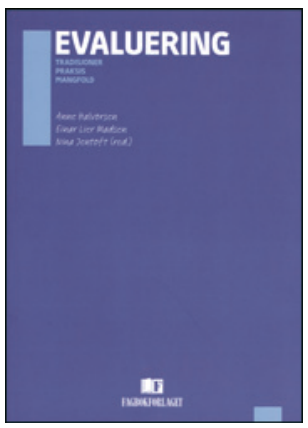

Anne Halvorsen, Einar Lier Madsen,

Nina Jentoft, red.

Evaluering

Tradisjoner, praksis, mangfold. 285 s, tab, ill. Bergen: Fagbokforlaget, 2012. Pris NOK 399 ISBN 978-82-450-1331-3

Vi har lenge hatt en situasjon der offentlig ansatte fagfolk kan ta med seg jobben over i et privat konsulentfirma, med dobbelt lønn, men dette private evalueringsmarkedet er muligens i ferd med å stagnere (1). Kanskje er det billigere - og bedre? - evalueringskompetanse på det offentlige og halvoffentlige markedet?

Denne boken er basert på noen av innleggene på Evalueringskonferansen 2011, arrangert av det norske evalueringsnettverket EVA-forum, som er organisert under Direktoratet for økonomistyring (2) og Fafo. En redaksjon på tre samfunnsvitere har gjort en god sammenskrivingsjobb, men boken bærer likevel preg av at «man tager hvad man haver». Et overordnet mål er gjennom en rekke eksempler å gi svar på hva slags evalueringskompetanse som finnes her til lands.

Evaluering er et relativt nytt fagområde i Norge, der man fremdeles søker etter de gode begrepene og metodene. Et grunnleggende spørsmål er relasjonen mellom forskning og evaluering. Er det egentlig noen forskjell? Mange av forfatterne prøver seg på denne problemstillingen, med vekslende hell. Det beste svaret kommer etter min mening i det siste kapitlet, Kvalitet og kunnskapsakkumulasjon i evaluering, av Osland og Elvebakk. De tar til orde for at evalueringsfeltet bør utvikle «funksjonelle ekvivalenter» til det normative rammeverket for forskning, i praksis særlig transparens og etterprøvbarhet. Forskning skal altså ikke være identisk med evaluering, men evalueringens kvalitet må baseres på velkjente forskningsprinsipper.

Noen kapitler fenger interessen. I sitt bidrag Evaluering av lover peker Nordrum overbevisende på at slik evaluering lett kan bli absurd: «Det bør ikke bli slik at målbarhet blir en forutsetning for lovgivning - det kan stå i veien for lover som mange ser hensiktsmessige. Det kan være at lover virker selv om ikke virkningen kan måles (s. 94).» Merk dere det, alle skapjuridiske medisinere som vil ha dokumentasjon og retningslinjer for alt.

Et annet høydepunkt: Nestor i norsk evalueringsforskning, Bergljot Baklien, skriver sammen med Astrid Skatvedt om følgeforskningens rotete roller og minner oss om at alle evalueringsforskere også er mennesker, og at det heller ikke i evalueringsjungelen finnes helt objektive sannheter.

Å skrive en bokmelding er også en evaluering, men forfatterne diskuterer ikke slike «enmannsevalueringer». Det nærmeste er nok nettopp Bakliens kapittel om følgeforskning. Men det er kanskje heller ingen av Tidsskriftets lesere som forventer at en bokanmeldelse som denne skal være objektiv og etterprøvbar?

Olaf Gjerløw Aasland

LEFO - Legeforskningsinstituttet

\footnotetext{
Litteratur

1. http://dn.no/forsiden/naringsliv/article2462670.ece (2.6.2013)

2. http://dfo.no/no/Styring/Faglige-nettverk/Nettverk-for-evaluering/ (2.6.2013).
}

\section{Hvordan ødelegge sykehus}

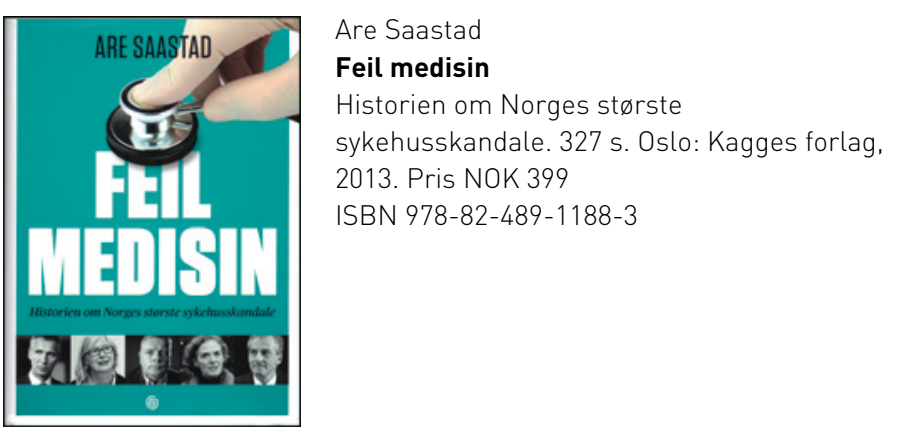

Det viktigste dokumentet med en analyse av opprettelsen av Oslo universitetssykehus er en lysbildeserie fra et konsulentfirma. Sykehusets første direktør, Siri Hatlen, fremla en plan for fremdriften av sykehusfusjonen, og i 2015 skulle hele Oslo universitetssykehus være samlet på Gaustad. Bente Mikkelsen, som ble fjernet som direktør i Helse Sør-Øst, lovet økonomisk overskudd innen 2012 som følge av sammenslåingen. Nåværende direktør, Bjørn Erikstein, klarer ikke å løse dagens enorme plassproblemer. Han planlegger «Campus Oslo»500000 kvadratmeter nybygg over 1,1 km av Store Ringvei ved Rikshospitalet - en prosess som vil ta minimum 20 år. Helseminister Jonas Gahr Støre er fascinert av IT-løsninger, men angir ingen løsninger på dagens store problemer i Oslo universitetssykehus. Avgått departementsråd Anne Kari Lande Halse har nylig kommet med en ny og hittil ukjent hovedårsak til sammenslåingen av Helse Sør og Helse Øst i 2007. Dette feilgrepet banet vei for sykehusskandalen.

Denne situasjonen med manglende forberedelser, urealistiske forestillinger, brutte løfter og avledningsmanøvre danner rammen for Are Saastads bok. Den vil engasjere, glede eller forarge alle som er interessert i sykehusdrift. Boken er innbundet, har et godt språk og er lett å lese. Det er et register med de 274 personene som omtales. Personomtalen er beskrivende, ikke dømmende. Det er 310 referanser, og teksten er en personlig beretning etter 35 år på Gaustad og Aker som pleiemedhjelper, hjelpepleier og tillitsvalgt i Fagforbundet. Forfatteren viser stor innsikt, god hukommelse og god systematikk. I all hovedsak følger boken en tidsakse som starter med prosessen bak foretaksreformen som ble innført i 2002, og endringene i Oslo-sykehusene frem til i dag.

Med utgangspunkt i psykiatrien trekker Saastad linjer til avdelings- og sykehusledelse, departement, storting, regjering og egen fagforening.

Saastad avkler prosessen i egen fagforening og problematiserer at en rekke av hans fagforeningsvenner har fremvist ekstrem autoritetstro. Dette har relevans for Legeforeningen og mange kolleger i ledelse. Det er grunn til å spørre hvilke vurderinger Legeforeningen sentralt har gjort gjennom prosessen. Det kan virke som om det har vært viktigere å være på bølgelengde med beslutningstakerne fremfor å gi støtte til medlemmene i Oslo universitetssykehus. Det har vært skuffende å se kolleger gå inn i ledelsesposisjoner og vektlegge økonomi og driftseffektivitet mer enn humane hensyn og pasientperspektiv.

Alle som er interessert i sykehusdrift, vil finne at boken er av stor verdi. Det er en glimrende kombinasjon av personlige opplevelser, fakta og vurderinger.

\section{Steinar Solberg}

Thoraxkirurgisk avdeling

Oslo universitetssykehus, Rikshospitalet 